\title{
Czym jest sobór dla Kościoła? Perspektywa rzymskokatolicka
}

Kościół pierwszych wieków kształtował swoją tożsamość zgodnie z zasadami współistnienia jako communio różnych tradycji kulturowych, liturgicznych i teologicznych znajdujących płaszczyznę porozumienia w poczuciu uczestnictwa w tej samej prawdzie, potwierdzanej przez Świętą Tradycję apostolską i patrystyczną i realizowanej w duchu wzajemnych siostrzano-braterskich odniesień. Oznacza to szacunek wobec różnych sposobów wyrażania i przeżywania wiary oraz poczucia wspólnoty z Bogiem i między sobą. Tak na przykład pluriformizm liturgiczny nie stanowił przeszkody w kształtowaniu siostrzanych relacji między lokalnymi wspólnotami. Był raczej znakiem i świadectwem duchowego bogactwa Kościoła. Siostry i bracia w tej samej wierze mogli się nawzajem obdarowywać kulturowym dziedzictwem, które stanowiło dla nich „naturalne” środowisko życia. Można więc powiedzieć, że płaszczyzna braterskich odniesień była dla Kościoła pierwszego tysiąclecia wręcz warunkiem jego egzystencji ${ }^{1}$.

${ }^{1}$ Zob. Z. Glaeser, Ku eklezjologii „Kościołów siostrzanych”. Studium ekumeniczne, Opole 2000, s. 86 . 
Szczególną przestrzenią budowania i urzeczywistniania kościelnej komunii były i do dziś pozostają sobory.

\section{Ustalenia formalno-terminologiczne}

Z punktu widzenia rzymskokatolickiego sobór jest uroczystym zgromadzeniem kolegium biskupów i innych przedstawicieli Kościoła obradującym wraz i pod przewodnictwem biskupa Rzymu lub jego przedstawiciela - legata. Obrady soboru dotyczą ważnych zagadnień Kościoła, a zwłaszcza jego jedności w sprawach dogmatycznych i organizacyjnych. Instytucja soboru nawiązuje do spotkania apostołów w Jerozolimie (ok. 50 r.). Na spotkaniu tym, zwanym tradycyjnie Soborem Jerozolimskim, rozstrzygnięto m.in., że chrześcijanie nawróceni z pogaństwa nie muszą poddawać się przepisom tradycyjnego prawa żydowskiego².

Dotychczas odbyły się następujące sobory, które Kościół rzymskokatolicki traktuje jako powszechne, czyli ekumeniczne: Sobór Nicejski (325), Sobór Konstantynopolitański (381), Sobór Efeski (431), Sobór Chalcedoński (451), Sobór Konstantynopolitański II (553), Sobór Konstantynopolitański III (680), Sobór Nicejski II (787), Sobór Konstantynopolitański IV (869), Sobór Laterański I (1123), Sobór Laterański II (1139), Sobór Laterański III (1179), Sobór Laterański IV (1215), Sobór Lyoński I (1245), Sobór Lyoński II (1274), Sobór w Vienne (1311-1312), Sobór w Konstancji (1414-1418), Sobór w Bazylei-Ferrarze-Florencji-Rzymie (1431-1445), Sobór Laterański V (1512-1517), Sobór Trydencki (1545-1547, 1551-1552, 1562-1563), Sobór Watykański I (1869-1870), Sobór Watykański II $(1962-1965)^{3}$.

${ }^{2}$ Zob. J. Dyl, J. Kędzierski, Sobory powszechne, [w:] Leksykon teologii fundamentalnej, red. M. Rusecki, Kraków 2002, s. 1114-1122; R. Minnerath, Sobory, tłum. A. Kuryś, Warszawa 2004, s. 5.

${ }^{3}$ Zob. J. Dyl, J. Kędzierski, Sobory powszechne, dz. cyt., s. 1116; E. Gigilewicz, Sobór powszechny, sobór ekumeniczny, [w:] EK, t. 18, Lublin 2013, k. 477-478; E. Sztafrowski, 
Kościoły prawosławne oraz protestanckie odwołują się do pierwszych siedmiu soborów. Te uznają za ekumeniczne ze względu na to, że były one soborami Kościoła niepodzielonego ${ }^{4}$. Tożsamość chrześcijańska wypływająca ze świadomości jednego chrztu udzielanego w imię Trójjedynego Boga oraz z wiary w Jezusa Chrystusa miała jeszcze wtedy pierwszeństwo przed tożsamością eklezjalną w znaczeniu konfesyjności ${ }^{5}$. To właśnie świadomość bycia chrześcijaninem sprawiła, że trudności, jakie wynikały z odmienności interpretowania niektórych prawd wiary, ówczesny Kościół pragnął rozwiązywać poprzez zwoływanie soborów, a w wymiarze lokalnym - synodów. Tak zwane sobory ekumeniczne były wyrazem komunii Kościołów. Gromadziły bowiem przedstawicieli wszystkich wielkich tradycji chrześcijańskich, aby bronić depozytu wiary przed zniekształceniami lub zafałszowaniem ${ }^{6}$. Sobory powszechne Kościoła niepodzielonego „stanowiły jakby momenty podsumowania życia Kościoła”. Kościoły Wschodu i Zachodu, świadome wspólnego dziedzictwa i tego samego fundamentu wiary, Jezusa Chrystusa, razem starały się zażegnywać niebezpieczeństwa herezji i rozłamów. Archetypem wspólnie

W. Łydka, Sobory, [w:] Słownik teologiczny, t. 2, red. A. Zuberbier, Katowice 1989, s. $246-250$.

${ }^{4}$ Szerzej zob. M. Starowiejski, Sobory Kościoła niepodzielonego, cz. 1: Dzieje, Tarnów 1994; F. Bécheau, Historia soborów, tłum. P. Rak, Kraków 1998.

${ }^{5}$ Por. W. Hryniewicz, Tożsamość, do której dążymy. Rozważania nad konfesjonalizmem i tożsamościa otwarta, [w:] Dialog Kościołów a tożsamość wyznaniowa. Materiały sympozjum ekumenicznego z okazji 10-lecia Instytutu Ekumenicznego KUL zorganizowanego w Lublinie w dniach 8-9 XI 1993 przez Instytut Ekumeniczny KUL oraz Instytut Teologiczno-Pastoralny filię KUL w Opolu, red. Z. Glaeser, S. J. Koza, R. Pierskała, Opole 1994, s. 86-87.

${ }^{6}$ "Starożytny Kościół nazywał swe sobory i synody ekumenicznymi wtedy, gdy reprezentowani na nich byli chrześcijanie nie tylko jednej prowincji, lecz całego cesarstwa, a więc całego znanego wówczas świata". Zob. Z. Glaeser, Wjednym Duchu jeden Kościót. Pneumatologiczna eklezjologia Nikosa A. Nissiotisa, Opole 1996, s. 184, przyp. 1. Por. także S. Nagy, Kościół na drogach jedności, Wrocław 1985, s. 18-21; A. Skowronek, Odkrywanie jedności, Warszawa 1988, s. 9-14.

${ }^{7}$ Jan Paweł II, Przemówienie do patriarchy Dimitriosa I (Fanar, katedra św. Jerzego, 29 XI 1979), [w:] Jan Paweł II w dialogu miłości z Kościołem wschodnim, oprac. A. Polkowski, Warszawa 1984, s. 120. 
sprawowanych zgromadzeń synodalnych był tzw. Sobór Apostolski w Jerozolimie (por. Dz 15, 1-35). Ukazywał on największy stopień jedności i współdziałania, przede wszystkim jednak współodpowiedzialności wszystkich apostołów za młody wówczas w swym istnieniu Kościół. W duchu miłości i prawdy, biorąc pod uwagę sugestie wszystkich obradujących, starsi i apostołowie rozstrzygali spory, jakie miały miejsce w ówczesnym Kościele. Czynili to w oparciu o zasadę równości wypływającą z zaufania wobec Bożego Ducha (por. Dz 15, 28).

Późniejsze sobory powszechne i synody lokalne pierwszego millenium stanowią dla Kościoła równie wielką wartość. Trzeba w nich widzieć instancję wyjaśniającą i rozwiązującą problemy istotne dla całego chrześcijaństwa. Zgromadzenia synodalne i soborowe opierały się na autorytecie samego Boga, nie zaś na autorytecie tych, którzy w Kościele piastowali urzędy ${ }^{8}$. Sobory powszechne i synody lokalne pierwszego tysiąclecia gromadziły braci w wierze, by w poczuciu braterskiej miłości, z uwzględnieniem równości lokalnych wspólnot, formułować dogmaty, bronić prawowierności nauki, a także aby nieustannie podtrzymywać jedność Kościoła9.

Dogmaty, jakie zostały wówczas sformułowane, dotyczyły ważnych spraw, zarówno dla całego Kościoła, jak i dla poszczególnych jego członków. W swym fundamentalnym wymiarze były wynikiem zatroskania tych, którzy przewodzili lokalnym wspólnotom, aby zachować prawowierność i jednorodność w nauczaniu prawd wiary. W formułowaniu orzeczeń soborowych uczestniczyli chrześcijanie różnych tradycji, co miało tym większe znaczenie dla ukazania siostrzano-braterskich relacji, w oparciu o które kształtowane było życie Kościołów. Na zgromadzeniach soborowych uwzględniano

${ }^{8}$ Zob. G. Larentzakis, Die Orthodoxe Kirche. Versuch einer Selbstdarstellung, „Ökumenisches Forum" 5 (1992), s. 119.

${ }_{9}$ Por. E. Suttner, Die Christenheit aus Ost und West auf der Suche nach dem sichtbaren Ausdruck für ihre Einheit, Würzburg 1999, s. 29-32. 
różnice, wynikające z odmienności kultur ${ }^{10}$. Uwieńczeniem wszelkich postanowień wspólnotowych pierwszych wieków, a zarazem wyrazem głębokich familiarnych więzów łączących lokalne wspólnoty, było sformułowanie „symbolu wiary”, zaaprobowanego przez cały chrześcijański świat i stanowiącego po dziś dzień podstawową płaszczyznę zgodności między chrześcijanami różnych konfesji ${ }^{11}$.

Soborowe orzeczenia były często reakcją na spory i błędne nauki głoszone przez niektórych członków Kościoła ${ }^{12}$. Negatywne stanowisko, jakie czasem zajmowały sobory wobec błędów w teologicznym nauczaniu, było również przejawem głębokiej troski o siostry i braci w jednej wierze. Odwoływanie się, w sprawach trudnych, do soborowych zgromadzeń służyło przede wszystkim budowaniu i utrwalaniu jedności między Kościołami lokalnymi. Kościół, kierując się troską o jedność, świadom odpowiedzialności za wszystkich wierzących i za wszystkie wspólnoty lokalne, poprzez soborowe decyzje, podejmowane w miłości i prawdzie, poszukiwał rozwiązań, które w duchu braterstwa i poczucia wspólnoty z całym chrześcijańskim światem kreśliły jego tożsamość.

W pierwszym millenium, na całej orbis Christiana, Kościół pozostawał niepodzielony - również w wymiarze zewnętrznym. Mimo różnic, które można było już wówczas zauważyć, nie zachodziły spory, które miałyby wymiar ogólnokościelny. Jedność i spoistość starożytnego chrześcijaństwa były silniejsze od tendencji destruktywnych. Kościoły spajało przede wszystkim poczucie siostrzano-braterskich więzów istniejących między nimi ${ }^{13}$.

\footnotetext{
${ }^{10}$ Por. H. J. Sieben, Zur Entwicklung der Konzilsidee, „Theologie und Philosophie” 45 (1970), s. 364-369.

${ }^{11}$ Zob. H. G. Beck, Kirche und Theologische Literatur im byzantinischen Reich, München 1959, s. 44-45.

${ }^{12}$ Por. W. de Vries, Die Struktur der Kirche gemäss dem ersten Konzil von Nikäia und seiner Zeit, [w:] Wegzeichen. Festgabe zum 60. Geburtstag von Prof. Dr. Hermenegild Biedermann, Hg. E. Suttner, C. Patock, Würzburg 1971, s. 55-81.

${ }^{13}$ Por. Z. Glaeser, Ku eklezjologii „Kościołów siostrzanych”. Studium ekumeniczne, dz. cyt., s. 86-88.
} 


\section{Aspekt historyczno-teologiczny}

W teologii rzymskokatolickiej funkcjonują zasadniczo dwie opinie dotyczące pochodzenia i legitymizacji instytucji soborowych. Zgodnie z pierwszą instytucja ta nie pochodzi z ustanowienia Bożego. Istotnym argumentem uzasadniającym zaprezentowane przekonanie jest brak wystarczających przesłanek biblijnych, które potwierdzałyby nakaz zwoływania soborów oraz określałyby ich istotę. Druga opinia opiera się na przekonaniu, że wspólne podejmowanie przez biskupów decyzji w sprawach dotyczących całego Kościoła pojawia się bardzo wcześnie jako jeden ze sposobów wykonywania władzy rządzenia i nauczania udzielonej biskupom przez Jezusa Chrystusa. Tak więc sobór, jako przejaw ustroju nadanego Kościołowi przez Boga, zawiera w swej istocie elementy pochodzące wprost z ustanowienia Bożego. Sposób jednak ich przejawiania się w konkretnych zgromadzeniach soborowych wykazuje zmienność, która pozwala wyróżnić w historii soborów kolejne epoki, w zależności od występującego w nich typu soborów powszechnych. Zasadniczo wyróżnia się sobory „wschodnie” i sobory „zachodnie”. Nie oznacza to, jakoby pierwsze były jedynie soborami Kościoła wschodniego, a drugie zgromadzeniami Kościoła zachodniego. Chodzi raczej w tym przypadku o kryterium związane z lokalizacją poszczególnych soborów. O ile pierwsze osiem soborów powszechnych miało miejsce na terenie Kościoła wschodniego, o tyle wszystkie późniejsze obradowały na obszarze Kościoła zachodniego. Przyznać jednak należy, że podane rozróżnienie nie opiera się jedynie na kryterium terytorialnym, ale wskazuje także na różnice wewnętrzne, jakie istnieją pomiędzy obydwoma typami soborów.

Eklezjologia rzymskokatolicka opiera się na dotyczącym konstytucji Kościoła przekonaniu, że jest on zbudowany na fundamencie apostołów, którzy na czele z Piotrem tworzą communio apostolorum. Od początku dziejów Kościoła wspólnie rozstrzygano wszelkie poważne problemy kościelne, zwłaszcza te, które zagrażają jego jedności. Szczególnym tego przykładem jest tzw. Sobór 
Jerozolimski ${ }^{14}$. Choć w prowadzonych na nim dyskusjach uczestniczyli także wierni, miał on jednak strukturę hierarchiczną. Głos decyzyjny należał do apostołów i starszych. Decyzje podejmowane były w czasie obrad z przekonaniem o asystencji Ducha Świętego.

Już w drugiej połowie II wieku istnieje w Kościele praktyka zgromadzeń biskupów ze sobą sąsiadujących, jak również biskupów reprezentujących różne regiony. Celem tych zgromadzeń jest debata nad aktualnymi problemami Kościoła i rozstrzyganie ważnych kwestii, wymagających jednolitości w nauczaniu i w życiu Kościoła. Kościół stopniowo dostrzegał coraz wyraźniej, że biskupi realizują dziedzictwo zadań apostolskich, a episkopat jako całość jest przedłużeniem apostolskiego kolegium. Stąd przekonanie o tym, że biskupi ponoszą współodpowiedzialność za cały Kościół, a nie tylko za lokalny Kościół, któremu przewodzą. Stąd wywodzi się ich udział w podejmowaniu decyzji wykraczających terytorialnie poza granice zarządzanej przez każdego z nich diecezji, a dotyczących istotnych spraw dla całego Kościoła, np.: problem gnozy, spór paschalny, problem upadłych w wierze, zagadnienie ważności chrztu udzielanego przez heretyków, dyskusje trynitarne i chrystologiczne ${ }^{15}$.

Najwcześniejsze zebrania biskupów miały miejsce w Azji Mniejszej około 175 roku, kiedy to biskupi wraz z wiernymi podjęli próbę rozstrzygnięć problemu montanistów. W tym czasie nie są znane podobne zebrania ani w pozostałych częściach Wschodu, ani tym bardziej na Zachodzie, który nie posiada wówczas jeszcze odpowiednio licznego episkopatu. Około 190 roku tzw. spory paschalne doprowadziły do kolejnych synodów. Zachętą do nich był list biskupa Rzymu Wiktora skierowany do poszczególnych Kościołów w celu poznania ich opinii na temat daty obchodzenia

${ }_{14}$ Zob. T. Fahy, The Council of Jerusalem, „The Irish Theological Quarterly” 30 (1963), s. 231-261; P. Gaechter, Geschichtliches zum Apostelkonzil, „Zeitschrift für katholische Theologie" 85 (1963), s. 339-354; H. Bogacki, Teologia soboru powszechnego w przygotowaniu i obradach I Soboru Watykańskiego. Studium historycznodogmatyczne, Warszawa 1965, s. 63-92.

${ }^{15}$ Zob. H. Bogacki, Teologia soboru powszechnego..., dz. cyt., s. 65. 
Wielkanocy, równocześnie zachęcający Kościoły lokalne do przyjęcia w tej kwestii praktyki rzymskiej. Ruch synodalny rozpoczyna wówczas pierwszy znany w historii synod rzymski odbyty pod kierunkiem papieża Wiktora. Po nim zwołano synody w innych prowincjach kościelnych, zwłaszcza wschodnich, posiadających najliczniejsze episkopaty ${ }^{16}$. Synodom tym przewodniczyli najczęściej biskupi miast odgrywających przewodnią rolę w danym rejonie. Wymiana poglądów między poszczególnymi synodami i biskupami następowała za pomocą listów. Wiele z nich kierowanych było także do biskupa Rzymu.

Wkrótce potem ruch synodalny zaczął się rozwijać w Afryce. Istotnym problemem dla tego regionu była konieczność rozstrzygnięcia sporu dotyczącego ważności chrztu udzielanego przez heretyków (220 r.). W Egipcie aktualne były wówczas tzw. spory orygeniczne. Około połowy III wieku dyskusja nad zagadnieniem chrześcijan odpadłych podczas prześladowań doprowadziła do nowego ożywienia aktywności synodalnej w całym Kościele ${ }^{17}$.

Wzmożony ruch synodalny w III wieku wpłynął na pogłębienie zrozumienia roli episkopatu w Kościele. Teologię episkopatu najjaśniej wyrażał w tym czasie św. Cyprian z Kartaginy. Synody postrzegał on jako wyraz jedności episkopatu. Zgodnie z jego przekonaniem, synod jest zwyczajnym sposobem uzgadniania wspólnego stanowiska co do aktualnych zagadnień ważnych tak dla całego Kościoła powszechnego, jak i dla poszczególnych prowincji kościelnych. Stąd też w Kościele afrykańskim powstał zwyczaj odbywania dorocznych synodów, podczas których biskupi wraz z kapłanami wspólnie rozstrzygali ważne problemy Kościołów. W ten sposób wśród biskupów panowała jedność przekonań i postępowania, gwarantująca jedność Kościoła. Cyprian reprezentował poglądy

${ }^{16}$ Zob. H. Grotz, Die Hauptkirchen des Ostens von den Anfangen bis zum Konzil von Nikaia (325), Rom 1964, s. 126-162.

${ }^{17}$ Zob. H. Bogacki, Teologia soboru powszechnego..., dz. cyt., s. 66-67; K. Schatz, Sobory powszechne. Punkty zwrotne w historii Kościoła, tłum. J. Zakrzewski, Kraków 2001, s. 15. 
eklezjologiczne charakterystyczne dla Afryki i chrześcijańskiego Wschodu, gdzie akcentowano przede wszystkim doniosłość wspólnoty kościelnej. Urząd Piotrowy traktowano jako wyraz, a nie źródło jedności Kościoła. W tym samym czasie biskupi rzymscy podkreślali, że ich własne decyzje stanowią normę wiary i postępowania dla chrześcijaństwa, a więc tym samym są źródłem jedności Kościoła. W ten sposób już w III wieku zrodziły się dwie zasadnicze koncepcje eklezjologiczne dotyczące ustroju Kościoła. Zgodnie z pierwszą, podkreślano przede wszystkim synodalny ustrój Kościoła, zwolennicy drugiej w urzędzie biskupa Rzymu dopatrywali się źródła jego jedności.

W drugiej połowie III wieku ruch synodalny rozpowszechniał się przede wszystkim na Wschodzie. Jednocześnie tu zaznaczają się w dziedzinie teorii soboru pewne znamienne cechy towarzyszące koncepcji synodu także w następnych wiekach. Już bowiem w okresie przednicejskim autorytet synodu jest tym wyższy, im liczniejsi biskupi w nim uczestniczą. Od zebranych biskupów oczekuje się wspólnego podjęcia zgodnej decyzji, a różnice występujące czasami między synodami odbytymi w różnych prowincjach są odczuwane jako zło zagrażające jedności wspólnoty chrześcijańskiej. Synod bowiem zmierza nie tylko do uzyskania jednomyślności między uczestnikami, lecz również do uznania jego uchwał przez pozostałych biskupów tego terytorium lub nawet całego Kościoła ${ }^{18}$. Stąd powstaje konieczność redagowania przez zgromadzenia biskupów listów synodalnych informujących o podejmowanych decyzjach, a zarazem nakłaniających innych biskupów do akceptowania ich treści. W rezultacie biskupi byli przekonani co do tego, że wiążą ich uchwały odbytych synodów, zwłaszcza gdy te zyskały uznanie całego Kościoła. Synody stanowią więc wyraz wspólnoty kościelnej, a zarazem są środkiem pogłębienia w Kościele świadomości tej wspólnoty.

Charakter rozpatrywanych zagadnień wpływał na większy lub mniejszy udział biskupów w owych synodach. Pierwsze zebranie

\footnotetext{
${ }^{18}$ Zob. H. Bogacki, Teologia soboru powszechnego..., dz. cyt., s. 68.
} 
episkopatu, które zyskuje miano soboru ekumenicznego, a więc obejmującego biskupów Kościołów rozsianych po całej zamieszkanej ziemi, to zjazd zwołany do Nicei w 325 roku przez cesarza Konstantyna, który już wcześniej zgromadził biskupów Zachodu na synodzie w Arles w 314 roku, a potem w Tyrze w 335 roku.

Postępowanie Konstantyna stało się wzorem dla następnych cesarzy, którzy z własnej inicjatywy, choć czasem za sugestią lub w porozumieniu z biskupem Rzymu, zwoływali sobory zarówno te, które obejmowały mniejszą ilość biskupów, jak i liczniejsze, nazywane potem „ekumenicznymi”. Ani cesarze, ani Kościół nie uważali takiego działania za uzurpację, lecz traktowali je jako normalny przejaw troski cesarzy o dobro państwa i Kościoła, jako obowiązek wynikający z pozycji cesarza w Kościele. Cesarze działali w pełni świadomi swej władzy i prawa nałożenia biskupom obowiązku udania się na sobór, a zarazem posiadali niezbędne środki materialne konieczne dla zgromadzenia biskupów na jednym miejscu ${ }^{19}$.

Ekumeniczność w zrozumieniu ówczesnego Kościoła ukazuje się jako jedność biskupów pochodzących ze wszystkich regionów świata. Wspomnieć jednak należy o tym, że chrześcijański Zachód na pierwszych soborach był reprezentowany jedynie przez nielicznych delegatów. Przeważnie byli to legaci papiescy, którzy na soborze wyrażali opinie Zachodu co do omawianych spraw. Najczęściej były one wcześniej uzgadniane na synodach rzymskich. Soborom starożytności chrześcijańskiej przewodniczył czasem cesarz lub jego urzędnicy, kiedy indziej delegaci papiescy lub biskup cieszący się wśród uczestników szczególnym autorytetem ${ }^{20}$.

Uczestnicy soboru byli przeświadczeni co do tego, że wspólnie wyrażają jedność Kościoła, gdyż jako kolegium biskupie stanowią przedłużenie kolegium apostolskiego, któremu Chrystus przyobiecał na zawsze swą obecność oraz asystencję Ducha Świętego. Stąd płynie autorytet soboru, a jego decyzje traktowano jako bezwarunkowe,

\footnotetext{
${ }^{19}$ Zob. tamże, s. 69.

${ }^{20}$ Zob. tamże, s. 70-71.
} 
będące wyrazem woli Bożej. Sobór jest więc w przekonaniu Kościoła pierwotnego żywym wyrazem komunii Kościoła powszechnego reprezentowanego przez następców apostołów, w którym działa Chrystus i Duch Święty.

Pierwsze cztery sobory, zaliczane do ekumenicznych, były zatwierdzane przez cesarzy. Nie ma żadnego przekazu historycznego świadczącego o późniejszym potwierdzaniu ich przez ówczesnych papieży. Uczestniczenie i działalność legatów papieskich w czasie soborowych zgromadzeń nie nosiły cech formalnej aprobaty uchwał nieposiadających przedtem mocy prawnej. Nie występuje więc wyraźne rozróżnienie jakby dwóch oddzielnych instancji episkopatu i papieża. Istnieje tylko jeden zespół składający się z biskupów i papieża działającego za pośrednictwem swych legatów, choć rola papieża jako głowy Kościoła zaznacza się już wyraźniej w Efezie i w Chalcedonie. Ujawnia się tu wyraźnie wewnętrzna jedność organiczna soboru: zespolenie członków i głowy, bez wyróżniania lub przeciwstawiania tych elementów ${ }^{21}$. Zasadniczo zgoda biskupa rzymskiego co do podejmowanych uchwał wynikała z obecności i z udziału w soborze legatów papieskich. Inaczej sprawa wygląda w odniesieniu do zgromadzenia biskupów zwołanego na polecenie Tedozjusza Wielkiego do Konstantynopola w 381 roku. Nie uczestniczył w nim ani biskup Rzymu, ani jego legaci, ani też nikt z biskupów zachodnich. Sobór ten był zgromadzeniem episkopatu Kościoła wschodniego. Tymczasem w późniejszym okresie został on zaliczony do grupy soborów ekumenicznych, co nadaje niektórym jego aktom (wyznanie wiary, potępienie macedonianizmu) powage jurydyczną równą innym soborom uchodzącym za zgromadzenia całego episkopatu. Sytuacja ta jest istotna dla wyjaśnienia genezy listy soborów ekumenicznych. Uznanie soboru za „ekumeniczny”

${ }^{21}$ Jedyna ingerencja papieska z tego okresu nosząca cechy formalnej dezaprobaty dotyczy odrzucenia przez Leona I pseudokanonu 28. Soboru w Chalcedonie jako niezgodnego z decyzją Soboru Nicejskiego i podjętego pod nieobecność jego legatów. Zob. H. Bogacki, Teologia soboru powszechnego..., dz. cyt., s. 72. 
jest wynikiem skomplikowanego procesu, w którym niemałą rolę odgrywa przyjęcie i uznanie jego uchwał w całym Kościele. Dość wcześnie utrwala się w Kościele przekonanie o wyjątkowej funkcji pierwszych czterech soborów ekumenicznych. Stały się one swoistym kryterium oceny prawowitości następnych soborów ${ }^{22}$, przede wszystkim ze względu na podjęte na nich rozstrzygnięcia trynitarne i chrystologiczne.

Sobory stały się więc elementem stałym ustroju kościelnego. Już Sobór Nicejski wprowadza przepis zobowiązujący do odbywania dwukrotnie w roku synodów gromadzących biskupów każdej prowincji. Przepis ten powtarzają potem następne sobory. Praktyka synodalna rozwija się pełniej na Wschodzie niż na Zachodzie, gdzie rzadziej zwołuje się synody prowincjonalne. W IV wieku powstała w Konstantynopolu instytucja trwałego synodu złożonego z biskupów obradujących pod przewodnictwem patriarchy. Działała ona zespołowo i rozstrzygała kwestie doktrynalne i dyscyplinarne, jakie coraz liczniej wyłaniały się w miarę wzrostu znaczenia patriarchy konstantynopolskiego. Synod ten był instytucją stałą, istniejącą obok corocznie zwoływanego synodu prowincjonalnego. Udział w stałym synodzie brali biskupi aktualnie przebywający w Konstantynopolu, choćby nawet nie pochodzili z terytorium podległego władzy patriarchy. W ten sposób permanentny synod stał się narzędziem rozszerzenia władzy patriarchy Konstantynopola, a zarazem przyczynił się do ujednolicenia prawa kościelnego w Bizancjum ${ }^{23}$.

Podobny organ posiadali biskupi rzymscy w postaci synodu rzymskiego składającego się z kapłanów i urzędników kurii oraz sąsiednich biskupów. Jednakże synod ten nie posiadał formy stałej instytucji, lecz zwoływany był w związku z aktualnymi potrzebami Kościoła ${ }^{24}$.

${ }^{22}$ Zob. E. Sztafrowski, W. Łydka, Sobory, [w:] Stownik teologiczny, red. A. Zuberbier, Katowice 1998, s. 536-539.

${ }^{23}$ Por. H. Bogacki, Teologia soboru powszechnego..., dz. cyt., s. 74-75.

${ }^{24}$ Por. tamże, s. 75. 
Od drugiej połowy IV wieku odrębny typ stanowią synody rzymskie. Jedną z ich charakterystycznych cech jest to, że papież dominował na nich w sposób bardziej istotny, niż miało to miejsce w przypadku innych metropolitów. Podczas gdy ci ostatni najczęściej byli tylko primi inter pares, to synod rzymski praktycznie stanowił organ doradczy papieża. Liczba jego uczestników była nieokreślona. Prawo do uczestniczenia w synodzie mieli biskupi z rzymskiej prowincji kościelnej, to znaczy z całej środkowej i południowej Italii wraz z wyspami. Często uczestnikami synodów rzymskich byli również biskupi z innych prowincji kościelnych, którzy w Rzymie obecni byli przypadkiem (tzw. synod endemiczny). W późniejszym czasie w synodach często brali udział nie tylko biskupi, ale również prezbiterzy i diakoni rzymscy. Podejmowano na nich nie tylko regionalne problemy rzymskiej prowincji kościelnej, lecz także problemy ogólnokościelne. Poza problemami odnoszącymi się do wiary podejmowano też sprawy dotyczące złożenia biskupów z urzędu. Rzymskie synody przez całe pierwsze tysiąclecie były ważnym instrumentem rzymskiego rządzenia Kościołem przez papieża. Papieże mieli zwyczaj przygotowywania na tych synodach problemów, którymi później zajmowały się sobory powszechne ${ }^{25}$. Przed epoką gregoriańską decyzje rzymskich synodów wprawdzie nie miały żadnego automatycznego skutku prawnego w innych prowincjach kościelnych, jednak cieszyły się potencjalną uniwersalnością, ponieważ wytyczały linię, zgodnie z którą działali później papieże. Odbywały się one bardzo często: tylko w przypadku V stulecia mamy wiadomości o prawie trzydziestu takich zgromadzeniach ${ }^{26}$.

Co do teorii soboru, należy zauważyć różnice między koncepcjami wschodnimi ${ }^{27} \mathrm{i}$ zachodnimi. Wypływają one $\mathrm{z}$ odmiennych eklezjologii. Na Zachodzie na czoło wysuwa się zasada jedności Kościoła

\footnotetext{
${ }^{25}$ Zob. K. Schatz, Sobory powszechne..., dz. cyt., s. 20-21.

${ }^{26}$ Zob. H. J. Schmale, Synodus - synodale concilium - concilium, „Archivum Historiae Conciliorum" 8 (1976), s. 84.

${ }^{27}$ Szerzej na ten temat zob. NSO.
} 
wyrażająca się w podporządkowaniu całego Kościoła władzy jurysdykcyjnej biskupa Rzymu, a stosunek do tej władzy staje się w eklezjologii zachodniej czynnikiem decydującym o przynależeniu tak jednostki, jak i całych Kościołów lokalnych do wspólnoty kościelnej jako takiej. W przeciwieństwie do tak sformułowanego empiryczno-socjologicznego sposobu patrzenia na Kościół, na chrześcijańskim Wschodzie rozwija się mistyczno-sakramentalna eklezjologia, akcentująca kompletność i wystarczalność Kościoła lokalnego w ramach Chrystusowego Ciała. Jednocześnie jednak chrześcijański Wschód skłonny był przyznawać cesarzowi rolę analogiczną do pozycji zajmowanej na Zachodzie przez papieża. Do prerogatyw cesarzy należało więc zwoływanie soboru, przewodniczenie jego obradom i zatwierdzanie soborowych uchwał. Do VIII wieku papieże generalnie uznawali taką sytuację za możliwą do przyjęcia.

O ile więc eklezjologia rzymska wywodzi wszelkie uprawnienia i władzę w Kościele od św. Piotra, którego następcą jest biskup Rzymu, o tyle cesarze bizantyńscy skłonni byli mniemać, że nawet uprawnienia biskupa rzymskiego pochodzą z ich upoważnienia. $\mathrm{Na}$ Zachodzie coraz bardziej utrwalało się przekonanie, że decyzje papieskie mają moc obowiązującą w całym Kościele, a wszelkie rozstrzygnięcia podejmowane poza Rzymem, nawet przez sobory, zyskują moc obowiązującą jedynie dzięki ich potwierdzeniu przez papieża. Wschód uznaje, że wśród stolic biskupich Rzym zajmuje pierwsze miejsce i przysługuje mu prawo czuwania nad czystością doktryny, lecz nie może mieszać się w wewnętrzne sprawy Kościołów lokalnych, z których każdy w sposób pełny realizuje sakramentalnie tajemnicę Kościoła i cieszy się autonomicznością w ramach wspólnoty kościelnej. Prymat papieski jest więc odmiennie rozumiany przez chrześcijański Zachód i przez Wschód. Wschód nie był i nie jest skłonny ulegać bez dyskusji autorytetowi papieża. Akcentuje jednak wagę wspólnego podejmowania decyzji na soborach lub za pośrednictwem wymiany listów między hierarchami. Rzym natomiast oczekuje uznania, że pełnia władzy w Kościele należy do papieża. W związku z powyższym rysują się odrębne sposoby patrzenia na 
formę sprawowania władzy w Kościele: Wschód na pierwszym miejscu stawia wspólne podejmowanie decyzji na soborach, Zachód przyznaje prerogatywę pierwszeństwa papieżowi, a jego decyzje uznaje za obowiązujące w całym Kościele. Jemu też powierza możliwość rozstrzygania kwestii spornych.

Klaus Schatz, wybitny jezuicki historyk soborów, wyróżnia trzy zasadnicze typy zgromadzeń soborowych, związane z konkretnymi epokami historycznymi ${ }^{28}$ :

1. Cesarskie sobory starożytności (w epoce cesarstwa). Zalicza do nich pierwszych osiem (lub siedem) soborów ekumenicznych do VIII/IX wieku. Są one przyjmowane (łącznie z Soborem Nicejskim II, 787) zarówno przez Kościół rzymskokatolicki, jak i Kościoły prawosławne. Ich zasadniczym znamieniem jest to, że należą do tej samej oikoumene (świata), która koncentruje się wokół Konstantynopola jako centrum i stoi pod znakiem wschodniego cesarstwa. Ich zwołanie nastąpiło na mocy autorytetu cesarskiego. Do cesarza należała również ich organizacja techniczno-finansowa. Uchwały soborów stawały się prawem cesarskim i jako takie zyskiwały społeczne przełożenie i ogólne uznanie w Kościele. Zmienne było również znaczenie Rzymu i jego legatów w poszczególnych soborowych zgromadzeniach. Od piątego stulecia, wobec braku akceptacji Rzymu, sobory nie znajdowały przez długi czas „ekumenicznego” uznania. W ten sposób Rzym próbował zagwarantować linię ciągłości i prawowitości zwoływanym zgromadzeniom. Zyskiwały one coraz stabilniejszą formę i trwały autorytet. Mimo to wszystkie ekumeniczne synody pierwszego tysiąclecia zachowują wobec Rzymu i jego wskazań bardzo samodzielne stanowisko. Od piątego stulecia znajdują się one w polu oddziaływania ,pentarchii”, czyli pięciu wiodących siedzib biskupich, tzn. Rzymu, Konstantynopola, Aleksandrii, Antiochii i Jerozolimy, które następnie zostały nazwane ,patriarchatami”.

Kryzys soborowej instytucji daje o sobie znać już po Soborze Chalcedońskim. Wiąże się to bezpośrednio z tym, że od czasu

${ }^{28}$ K. Schatz, Sobory powszechne, dz.cyt., s. 11-14. 
najazdów barbarzyńskich w piątym stuleciu Zachód nie należy już do „Kościoła cesarskiego”. Należy wówczas do niego jeszcze Rzym, którego duchowy autorytet ma na Zachodzie wysoką pozycję. Z tego względu również Zachód, choć z opóźnieniami obejmującymi wiele stuleci, został wciągnięty w ów „ekumeniczny” proces.

2. Średniowieczne sobory chrześcijaństwa zachodniego. Były zgromadzeniami Kościoła zachodniego. Te z późnego średniowiecza były typami „soborów papieskich” (np. Sobór Laterański IV, 1215; Sobór Lyoński II, 1274). Odbywały się one pod przewodnictwem papieży. Ich cechą charakterystyczną był udział wszystkich „stanów” chrześcijańskich (nie tylko biskupów). Podejmowano na nich nie tylko problemy teologiczne oraz te związane z życiem i dyscypliną kościelną, ale także aktualne kwestie polityczne. Po tych soborach, zwanych również „soborami jedności i reformy”, nastąpiły „sobory koncyliarystyczne” w Pizie, w Konstancji i w Bazylei. Miały one charakter generalnych zgromadzeń chrześcijańskiego świata. Rozumiano je nie jako papieskie gremia doradcze ani jako zgromadzenia Kościołów lokalnych (tak jak dawne sobory), ale jako najwyższa instancja Kościoła powszechnego pojmowanego w sposób korporacyjny.

3. Katolickie sobory Kościoła konfesyjnego (Sobór Trydencki, Sobór Watykański I, Sobór Watykański II). Po rozłamie Kościoła zachodniego związanym z XVI-wieczną reformacją sobory przestały być zgromadzeniami chrześcijańskiego Zachodu bądź też chrześcijańskiego świata. Stały się zgromadzeniami Kościoła rzymskokatolickiego. W nowej sytuacji kościelno-społecznej były próbą określenia miejsca Kościoła rzymskiego w radykalnie zmieniającym się świecie. Uczestniczyli w nich przede wszystkim biskupi. Sobór Watykański II bardzo ostrożnie wprowadza jednak nowe formy obecności „świata” na soborze, zarówno przez przekazywanie wiadomości z soboru mediom, jak i przez obecność przedstawicieli innych, pozarzymskokatolickich Kościołów chrześcijańskich. Przy tym, poczynając od Soboru Trydenckiego, rola papieży jako tych, którzy przewodniczyli soborom, stale wzrastała. Relacja pomiędzy soborem i papieżem, którego 
urząd od czasów soborów w Konstancji i w Bazylei stał się przedmiotem dyskusji, mimo postanowień Soboru Watykańskiego I pozostała problemem nie do końca rozwiązanym.

\section{Aspekt kanoniczno-organizacyjny}

Najwyższa władza w Kościele rzymskokatolickim ${ }^{29}$ charakteryzuje się specyficzną, dwubiegunową strukturą. Jeden biegun stanowi kolegium biskupów z papieżem na czele ${ }^{30}$, drugi to papież w jedności z biskupami ${ }^{31}$. Sobór, jako uroczysta forma sprawowania władzy w Kościele ${ }^{32}$, urzeczywistnia jedność Kościoła powszechnego oraz ciągłość sukcesji apostolskiej. Do funkcjonowania soboru potrzebne są oba bieguny władzy: kolegium jako organ opracowujący dekrety oraz papież jako osoba zatwierdzająca wszelkie ustalenia. Obydwa należą do istoty soboru. Kościół nie wypracował jednak stałych

${ }^{29}$ W związku z tym szerzej zob. B. Sesboüé, Władza w Kościele. Autorytet, prawda i wolność, tłum. P. Rak, Kraków 2003; T. Pikus, O władzy w Kościele, Warszawa 2003.

30 „Kolegium Biskupów, którego głową jest Papież, a członkami biskupi na mocy sakramentalnej konsekracji oraz hierarchicznej wspólnoty z głową Kolegium i członkami, i w którym trwa nieprzerwanie ciało apostolskie, razem ze swoją głową, a nigdy bez niej, stanowi również podmiot najwyższej i pełnej władzy nad całym Kościołem". KPK, kan. 336.

31 „Biskup Kościoła Rzymskiego, w którym trwa urząd udzielony przez Pana samemu Piotrowi, pierwszemu z Apostołów, a który ma być przekazywany jego następcom, jest Głową Kolegium Biskupów, Zastępcą Chrystusa i Pasterzem całego Kościoła tutaj na ziemi. Dlatego, z racji swego urzędu, posiada on najwyższą, pełną, bezpośrednią i powszechną władzę zwyczajną w Kościele, którą może wykonywać zawsze w sposób nieskrępowany”. KPK, kan. 331. „W wykonywaniu zadania najwyższego Pasterza Kościoła Biskup Rzymski jest zawsze złączony wspólnotą z pozostałymi biskupami, a także z całym Kościołem. Jemu jednak przysługuje prawo określania - zgodnie z potrzebami Kościoła - sposobu, indywidualnego lub kolegialnego, wykonywania tego zadania”. KPK, kan. 333 § 2 .

${ }^{32}$ „Władzę w całym Kościele Kolegium Biskupów wykonuje w sposób uroczysty na soborze powszechnym”, KPK, kan. 337 §1. „Tę samą władzę wykonuje przez zjednoczoną działalność biskupów rozproszonych po świecie, która jako taka została przez Biskupa Rzymskiego zapowiedziana lub dobrowolnie przyjęta, tak żeby stała się prawdziwym aktem kolegialnym”. KPK, kan. 337 § 2 . 
metod przeprowadzania obrad soborowych. Zarówno struktura soboru, jak i sposoby komunikacji między uczestnikami zgromadzenia zmieniały się wraz z kontekstem historycznym. Poszczególne sobory pod względem organizacji i komunikacji różniły się zatem od siebie w sposób zasadniczy ${ }^{33}$.

Aktualne zasady funkcjonowania soboru bezpośrednio określają kanony 338-341 Kodeksu prawa kanonicznego z 1983 roku. Organem decyzyjnym w kwestiach organizacji i przebiegu soboru jest papież ${ }^{34}$. Do jego kompetencji należy wskazanie terminu rozpoczęcia i zakończenia obrad zgromadzenia powszechnego, wyznaczenie miejsca przeprowadzenia obrad lub jego ewentualna zmiana, ustalenie regulaminu soboru oraz tematów, które staną się przedmiotem dyskusji ${ }^{35}$. Propozycje tematów mogą być zgłaszane także przez ojców soborowych, jednak zostają włączone do programu obrad dopiero po uprzednim uzyskaniu zgody papieża.

Co do czynnego prawa do uczestniczenia w soborze praktyka zmieniała się w zależności od wielu czynników związanych ze zwołaniem soborowego zgromadzenia. Pierwsze sobory zwoływali cesarze. Oni też im przewodniczyli. Dopiero od Soboru Laterańskiego IV (1215) obowiązki te przejął papież. Biskupowi rzymskiemu przysługiwała możliwość wyznaczenia legatów, którzy w jego zastępstwie uprawnieni byli do przewodniczenia poszczególnym sesjom soborowym. Ze sposobności tej skorzystano na przykład podczas Soboru Trydenckiego (1545-1563), któremu przewodniczyło trzech papieskich legatów ${ }^{36}$. Obecnie soborowi z urzędu przewodniczy papież bądź wyznaczony przez niego delegat. Gdyby w czasie trwania soboru nastąpił wakat Stolicy Apostolskiej (w wyniku

${ }^{33}$ Zob. K. Sitkowska, Aspekty organizacyjne i komunikacyjne II Soboru Watykańskiego, „Kultura-Media-Teologia” (2013) nr 12, s. 9.

${ }^{34}$ Zob. tamże.

35 „Tylko Biskup Rzymski może zwołać sobór powszechny, przewodniczyć mu, osobiście lub przez innych, a także przenieść sobór, zawiesić lub rozwiązać, jak również zatwierdzać jego dekrety". KPK, kan. 338 §1.

${ }^{36}$ Por. K. Schatz, Sobory powszechne, dz. cyt., s. 175. 
śmierci lub zrzeczenia się urzędu przez papieża), zgromadzenie zostałoby automatycznie zawieszone. Dopiero wybór nowego biskupa Rzymu przywraca kolegium zdolność sprawowania władzy, także tej o charakterze uroczystym. Decyzja o kontynuowaniu lub rozwiązaniu przerwanego soboru należy do papieża ${ }^{37}$.

Podobnie jak osoba przewodniczącego, zmieniała się także struktura personalna soborów. Od czasów średniowiecza sobory były nie tylko zgromadzeniami biskupów, ale również wszystkich „stanów" chrześcijaństwa. Stąd poza biskupami uczestniczyli w nich także opaci, mnisi, przedstawiciele kapituł katedralnych, kościołów kolegialnych oraz książęta. Na przykład do udziału w Soborze Watykańskim I (1869-1870) zaproszono wszystkich biskupów oraz opatów i generałów zakonnych. Warunkiem uczestnictwa opatów i generałów było sprawowanie przez nich jurysdykcji podobnej do władzy biskupa. Prawo głosu, oprócz biskupów, miały także inne grupy osób ${ }^{38}$. Obecnie prawo do uczestnictwa w soborze z głosem decydującym mają członkowie kolegium biskupów, którzy zostali sakramentalnie konsekrowani i zachowują hierarchiczną łączność z papieżem i innymi członkami kolegium ${ }^{39}$. Mogą oni zabierać głos w czasie posiedzeń plenarnych oraz głosować nad dyskutowanymi schematami. Do udziału w zgromadzeniu mogą również zostać zaproszeni inni duchowni, zakonnicy i świeccy (także spoza Kościoła rzymskokatolickiego) w roli obserwatorów lub doradców. Ich funkcję i uprawnienia określa papie $\dot{z}^{40}$. Nie mają oni jednak ani prawa udziału

${ }^{37}$ „Gdyby się zdarzyło, że w czasie soboru zawakowałaby Stolica Apostolska, na mocy samego prawa sobór zostaje przerwany, dopóki nowy papież nie nakaże go kontynuować lub rozwiązać”. KPK, kan. 340.

${ }^{38}$ Zob. K. Sitkowska, Aspekty organizacyjne..., dz. cyt., s. 10.

${ }^{39}$ „Wszyscy i tylko biskupi, którzy są członkami Kolegium Biskupów, mają prawo i obowiązek uczestniczenia w soborze powszechnym z głosem decydującym”. KPK, kan. 339 §1. Zob. także KPK, kan. 336.

${ }^{40}$ „Najwyższa władza kościelna może wezwać na sobór powszechny również niektórych innych, nie mających godności biskupiej. Do niej też należy określić ich udział w soborze”. KPK, kan. 339 § 2. 
w głosowaniach, ani też możliwości wypowiadania się w czasie posiedzeń plenarnych. Dokumenty wypracowane przez sobór zyskują moc prawną dopiero po promulgowaniu ich przez papieża i po ich ogłoszeniu z jego polecenia ${ }^{41}$.

Częstotliwość zwoływania soborów nie jest określona żadnymi rozporządzeniami. Kwestię tę próbował usystematyzować dekret Frequens generaliom conciliorum Soboru Konstancjańskiego (14141418), który „zakładał zwoływanie soboru w regularnych odstępach czasu: najpierw w pięć lat po zakończeniu Soboru w Konstancji, potem co siedem lat, a w końcu co dziesięć lat. Papieże mogli przekładać terminy na czas wcześniejszy, ale nie wolno im było przekładać zwołania soboru na później. Zgodnie z zapisami ww. dekretu, przy końcu każdego soboru papież powinien ustalić, za zgodą soboru, miejsce przyszłego soboru. Tylko w przypadku wojny lub zarazy wolno było papieżowi zmienić je na korzyść innego miasta, które jednak powinno leżeć w obrębie tej samej nacji”" ${ }^{42}$. Postanowień tego dekretu nigdy nie wprowadzono jednak w życie.

Przepisy prawa kanonicznego nie ustalają konkretnych zasad, zgodnie z którymi powinny być przeprowadzane obrady soborowe. Nie precyzują także zasad dotyczących sposobów głosowania czy trybu uchwalania ustaw. Wszelkie decyzje w tym zakresie należą do papieża. Do jego kompetencji należy także wydawanie przepisów proceduralnych, obowiązujących w czasie soboru z uwzględnieniem przerw między sesjami oraz okresu recepcji po jego zakończeniu.

$* * *$

${ }^{41}$ „Dekrety soboru powszechnego nie posiadają mocy obowiązującej, dopóki, po zatwierdzeniu ich przez Biskupa Rzymskiego wraz z ojcami soboru, nie zostaną przez niego potwierdzone i na jego polecenie ogłoszone”. KPK, kan. $341 \S 1$. „Takiego samego potwierdzenia i ogłoszenia, dla uzyskania mocy obowiązującej, wymagają dekrety Kolegium Biskupów, gdy podejmuje działalność ściśle kolegialną, w sposób wskazany albo dobrowolnie przyjęty przez Biskupa Rzymskiego". KPK, kan. 341 § 2 .

${ }^{42}$ K. Schatz, Sobory powszechne, dz. cyt., s. 140. 
Wyżej przeprowadzone analizy pozwalają na wyciągnięcie wniosku, że teoria soboru ma charakter dynamiczny i rozwojowy. Różne rozkładanie akcentów w interpretacji sposobów sprawowania władzy w Kościele wiąże się ściśle z kontekstem historycznym, kościelno-społecznym i teologicznym czasu, w którym miały miejsce poszczególne sobory. Są one uroczystymi zgromadzeniami biskupów, którzy są reprezentantami (a nie delegatami) całego Kościoła. Były zwoływane przede wszystkim w sytuacjach kryzysów, zwłaszcza doktrynalnych. Sobory ekumeniczne Kościoła niepodzielonego ukształtowały kościelny fundament doktrynalny, dyscyplinarny i liturgiczny. Były wydarzeniami wyrażającymi tożsamość Kościoła. Uskuteczniały najwyższą i pełną władzę w Kościele. Nieco inaczej kształtowało się jej rozumienie na Wschodzie, inaczej na Zachodzie. W Kościele zachodnim, zwłaszcza po jego rozłamie w XVI wieku, coraz bardziej wskazywano na uprzywilejowaną rolę papieża w kolegium biskupów. To spowodowało, że papieżowi przyznano wyłączne prawo do zwoływania soboru, do przewodniczenia jego obradom i do zatwierdzania jego dokumentów.

Przypomnieć należy także o tym, że sobór uznaje się za ekumeniczny nie dlatego, że kieruje się zasadą ekumenicznej otwartości, ale dlatego, że jest wyrazem kościelnej komunii urzeczywistnianej w Duchu Świętym. Bez uwzględnienia roli Ducha Świętego w sprawowaniu kościelnego posługiwania nie sposób dogłębnie zrozumieć natury soborów.

\section{Bibliografia}

Bécheau F., Historia soborów, tłum. P. Rak, Kraków 1998.

Beck H. G., Kirche und Theologische Literatur im byzantinischen Reich, München 1959.

Bogacki H., Teologia soboru powszechnego w przygotowaniu i obradach I Soboru Watykańskiego. Studium historycznodogmatyczne, Warszawa 1965.

Dyl J., Kędzierski J., Sobory powszechne, [w:] Leksykon teologii fundamentalnej, red. M. Rusecki, Kraków 2002, s. 1114-1122. 
Fahy T., The Council of Jerusalem, „The Irish Theological Quarterly” 30 (1963), s. 231-261.

Gaechter P., Geschichtliches zum Apostelkonzil, „Zeitschrift für katholische Theologie" 85 (1963), s. 339-354.

Gigilewicz E., Sobór powszechny, sobór ekumeniczny, [w:] EK, t. 18, Lublin 2013, k. 477-478.

Glaeser Z., Ku eklezjologii „Kościołów siostrzanych”. Studium ekumeniczne, Opole 2000.

Glaeser Z., Wjednym Duchujeden Kościót. Pneumatologiczna eklezjologia Nikosa A. Nissiotisa, Opole 1996.

Grotz H., Die Hauptkirchen des Ostens von den Anfangen bis zum Konzil von Nikaia (325), Rom 1964.

Hryniewicz W., Tożsamość, do której dążymy. Rozważania nad konfesjonalizmem i tożsamościa otwarta, [w:] Dialog Kościołów a tożsamość wyznaniowa. Materiały sympozjum ekumenicznego z okazji 10-lecia Instytutu Ekumenicznego KUL zorganizowanego w Lublinie w dniach 8-9 XI 1993 przez Instytut Ekumeniczny KUL oraz Instytut Teologiczno-Pastoralny filię KUL w Opolu, red. Z. Glaeser, S. J. Koza, R. Pierskała, Opole 1994, s. 83-98.

Jan Paweł II, Przemówienie do patriarchy Dimitriosa I (Fanar, katedra św. Jerzego, 29 XI 1979), [w:] Jan Paweł II $w$ dialogu miłości z Kościołem wschodnim, opr. A. Polkowski, Warszawa 1984, s. 119-120.

Kałużny T., Nowy sobór ogólnoprawosławny. Natura, historia przygotowań, tematyka, Kraków 2008 [=NSO].

Kodeks prawa kanonicznego, Poznań 1984 [=KPK].

Larentzakis G., Die Orthodoxe Kirche. Versuch einer Selbstdarstellung, „Ökumenisches Forum" 5 (1992), s. 116-127.

Minnerath R., Sobory, tłum. A. Kuryś, Warszawa 2004.

Nagy S., Kościół na drogach jedności, Wrocław 1985.

Pikus T., O władzy w Kościele, Warszawa 2003.

Schatz K., Sobory powszechne. Punkty zwrotne w historii Kościoła, tłum. J. Zakrzewski, Kraków 2001.

Schmale H. J., Synodus - synodale concilium - concilium, „Archivum Historiae Conciliorum" 8 (1976), s. 80-102.

Sesboüé B., Władza w Kościele. Autorytet, prawda $i$ wolność, tłum. P. Rak, Kraków 2003.

Sieben H. J., Zur Entwicklung der Konzilsidee, „Theologie und Philosophi” 45 (1970), s. 353-389. 
Sitkowska K., Aspekty organizacyjne i komunikacyjne II Soboru Watykańskiego, „Kultura-Media-Teologia” (2013)12, s. 8-21.

Skowronek A., Odkrywanie jedności, Warszawa 1988.

Starowiejski M., Sobory Kościoła niepodzielonego, cz. 1: Dzieje, Tarnów 1994.

Suttner E., Die Christenheit aus Ost und West aufder Suche nach dem sichtbaren Ausdruck für ihre Einheit, Würzburg 1999.

Sztafrowski E., Łydka W., Sobory, [w:] Słownikteologiczny, t. 2, red. A.Zuberbier, Katowice 1989, s. 246-250.

Sztafrowski E., Łydka W., Sobory, [w:] Słownik teologiczny, red. A. Zuberbier, Katowice 1998, s. 536-539.

Vries W. de, Die Struktur der Kirche gemäss dem ersten Konzil von Nikäia und seiner Zeit, [w:] Wegzeichen. Festgabe zum 60. Geburtstag von Prof. Dr. Hermenegild Biedermann, Hg. E. Suttner, C. Patock, Würzburg 1971, s. 55-81.

\section{What is a Council to the Church? The Roman Catholic Perspective}

\section{SUMMARY}

Council is a solemn assembly of the college of bishops and other members of the Church with and under the leadership of the bishop of Rome or his envoy - legate. The councils deal with important and current issues of the Church, in particular concerning her unity in doctrine and organization. The Orthodox and Protestant Churches accept the first seven councils, considered ecumenical for called by undivided Church. These councils formed the ecclesiastic base of doctrine, discipline and liturgy. They also were events that expressed the identity of the Church and realized the highest and fullest authority of the Church. But its understanding varied in the East and the West. In the Western Church, in particular after the Reformation, the privileged role of the pope in the college of bishops was highlighted. It caused the pope to be considered the only person responsible to call the council, to preside it and to authorize its documents. The theory of council has a dynamic and evolutionary character. Different spreading of accents in the interpretation of the ways to exercise authority in the Church is related to the historical context, ecclesiastical, social and theological time, in which various councils gathered. 
A council is considered ecumenical not because it follows the principle of ecumenical openness, but because it is an expression of ecclesiastical communion implemented in the Holy Spirit. Without considering the role of the Holy Spirit in the exercise of ecclesiastical ministry, it is impossible to comprehend the nature of councils.

KEYWORDS: council, synod, Church, pope, authority, communion SŁOWA KLUCZOWE: sobór, synod, Kościół, papież, władza, komunia 